\title{
Deliberations about subjectivity and autonomy. A developmental approach
}

\section{Introduction}

The aim of this volume is to present the question of subjectivity and autonomy from the perspective of human development during the life course and attempt to extend and deepen, at least to a certain extent, knowledge concerning selected scopes and stages of development.

In psychological literature, the issue of human subjectivity and autonomy is not mainstreamed. The term "subject" or "subjectivity" cannot be found in the Dictionary of Psychology by Reber (1985), while the entry "autonomy", in the general sense, was defined with one word - independence. While autonomy can still be read about in psychology textbooks for students, subjectivity hardly gets any place in them. This fact may seem surprising in light of the meaning and importance of subjectivity in human development and functioning in various fields (see Obuchowski, 1977, 1995; Uchnast, 1990a \& b; Niemczyński, 1994, 2007; Popielski, 1994; Stachowski, 2002; Straś-Romanowska, 1999, 2004, 2011; Gasiul, 2006; and Jarymowicz, 2008), including the existential role of the subject-subject relationship (Zagórska, 2011, 2012, 2015a \& b).

Why does the importance of this issue not go handin-hand with the volume of theoretical considerations concerning this issue showcased in both Polish and international psychological literature? The concept of human subjectivity, which is ambiguous in psychology and rooted in philosophy, the essence of which is connected with an individual's free will, has shared the fate of the latter in psychology. The incapacity to reconcile free will with determinism has led to the removal - in the second half of the $20^{\text {th }}$ century - of the category of the "will" from the vocabulary of scientific psychology. "However, in so much as the term itself was effectively gotten rid of,"
Sotwin writes (2010), "psychology was, to this extent, incapable of describing neither the functioning of the mind, nor the behaviour of the human being without the content that this term entailed [...]. Hence, it introduced many other terms in its place, like 'subjective control', 'self-control', and 'causation'..." (Sotwin, 2010, p. 13). At present, a turn towards the concept of free will and subjectivity can be observed, although they have returned in academic psychology in a somewhat different than personalistic cover.

Contrary to personalistic and existential-phenomenological psychology, there have been few attempts to define the concept of subjectivity and autonomy in the psychosocial field. Thus, a closer look will be taken at selected approaches and definitions of subjectivity and autonomy in order to specify more accurately the functions that they fulfill in the general development and functioning of the human person. From this perspective, we will move on to refer to the texts included in the presented volume.

\section{Subjectivity and autonomy in selected theoretical approaches}

Various theoretical approaches to the issue of subjectivity can be found in psychological literature, albeit mainly within personality, cognitive and social psychology (Reykowski, 1988; Uchnast, 1990a \& b; Straś-Romanowska, 1999; Popielski, 1994; Majczyna, 2000; Gasiul, 2006; and Jarymowicz, 2008). At first, we will focus on two terms: the subject and subjectivity.

The subject, in the simplest dictionary definition (Podsiad, Więckowski 1983, col. 273), is a feeling or acting human being. The subject of psychological study is the sense of being the subject. The personal experience and experiencing the fact of being the subject are important 
in psychology. Subjectivity, according to Reykowski (1988), is primarily subjective activity driven by the goals selected or created by the subject. According to Reykowski, subjective activity gives the person their individuality.

In the view of Jarymowicz (2008), when we speak of the subject, we are taking a functioning person into account, whereas subjectivity signifies a set of traits of the subject which are responsible for their functioning. Self-reflection enables a person to perceive her/himself as a person and consider themself capable of taking on activities in the world.

It is worth pointing out two significant approaches to the issue of subjectivity in psychological literature (Sotwin, 2006). The former emphasises that subjectivity is an individual's gradual gaining control over the environment through the restriction of external pressures. The latter associates subjectivity with self-control and self-determination as well as the gradual reduction of internal pressures (relating to the human body and psyche). The authors of various concepts concerning the process of shaping a person's subjectivity (Jarymowicz, 2008; Sotwin, 2003, 2006) emphasise the necessity of becoming independent from both external and internal limitations.

Jarymowicz (2008) identifies three types of manifestations of subjectivity that are closely linked to areas of human functioning: 1) the signs of subjectivity connected with the orientation cognitive sphere (e.g., selfawareness, self-knowledge, defining one's identity, etc.); 2) those connected with the emotional and motivational sphere (e.g., the ability to assess oneself and the world, the formulation of goals, decision-making, and the creation of action programmes, etc.); and 3) those related to the executive sphere (e.g., the ability to exercise selfcontrol, personal causation, steering oneself and one's own development).

A different approach is perceiving subjectivity in light of the premises of personalism (Straś-Romanowska, 2010). The criterial features of the personal subject, which have been adopted here after the representatives of the vast philosophical anthropology mainstream, include: cognitive openness, axiological sensitivity, free will, and transgression. These attributes compound the personal potential of subjectivity that a person harnesses in various ways and to varying degrees throughout their life. Straś-Romanowska believes that being a subject is not merely an objective fact or a manner of existence which is characterised by intentional activity and causation but, above all, an ontological and existential fact connected with the personal condition and, at the same time, a life task. This means that the human being is a personal being endowed with specific attributes that define specific types of her/his activities. Subjective endowment, that is, the innate potential for subjectivity, in the opinion of StraśRomanowska (2010), imparts to the person the possibility of being a subject irrespective of the circumstances. A person, as a personal being, is a cognitively open being. This is because they are capable of being reflective not only based on knowledge and rational reasoning but also on experiences, which include the entirety of experiences, accompanied by feelings and intuitions. This results in a special kind of awareness - reflective self-awareness.

There is a tradition in personality psychology, reaching back to the works of James (1892), of distinguishing "the subjective Self" and the "objective Self" (cf. Bobryk, 1981; Pervin, John, 1997). “The objective Self” fulfils important functions in behavioural control thanks to selfawareness, self-knowledge, and the structure of the Self. The "subjective Self", on the other hand, is linked to the ability to control onself and to think about oneself. It is considered to be the centre of human activity (StraśRomanowska, 2004). The "personal Self" is connected with human existence, with their existence in the world and her/ his relationships with the world and with other beings.

The concept of autonomy is closely linked to the concept of subjectivity. It is usually associated with independence or self-reliance in thoughts and actions. There are many dimensions of autonomy that can be discussed, also in relation to feelings and emotions, cognitive functioning, actions or self-image. It is often accepted in psychological literature that the autonomy of an adult person is distinguished by a sense of the person's own individuality, independence, self-control, awareness of possessing a free will, awareness of a person being an independent entity, and a sense of being able to make choices.

The issue of autonomy in relation to human development has received a lot of attention from such prominent representatives as Piaget (e.g., Piaget, Inhelder, 1989) or Erikson (e.g., 1968, 1994), and more recently also from Labouvie-Vief $(1982,1992)$. However, the link between autonomy and human subjectivity is demonstrated more clearly in the field of personality psychology.

In Polish personality psychology, the issue of autonomy was tackled by Obuchowski (1977). According to him, autonomy signifies an individual's independence from someone or something, whereas personality autonomy is a criterion of development of human subjectivity in the social area of life. The human "Self" is shaped in the process of individuation with the participation of other persons. The psychological maturation of the human person is the process of moving from the state of social dependence to independence in terms of the formulation of life goals and tasks. According to Obuchowski, the attainment of psychological and social autonomy is a lifelong process despite being connected with different psychological needs at the relevant stages of development.

Straś-Romanowska (1999), however, believes that changes in a person's personality are driven by the individuation process and the advancement of autonomy. They result from the continuous reconstruction of the content of personal experience. Autonomy, that is, becoming independent from the outside world, knowledge of one's inner Self, needs and capabilities can be treated as a factor stimulating development. Jarymowicz (1988) sees this dependence in a similar way, linking the shaping of a person's personality and their subjectivity and autonomy to the individuation process. 
The issue of autonomy from the perspective of individual development during the life course has been studied in Poland by Niemczyński (1992, 1994, 2007) for over two decades. He developed an original theory concerning autonomous personal development as a process lasting an entire lifetime and creating its own, internal normative model. In contrast to other authors, Niemczyński considers understanding autonomy as an absolute independence as an error. He claims that "the autonomy of individual person development does not consist of becoming independent from other areas but is rather expressed in personal, not reduced to others, rules for the playing out of processes in this area" (Niemczyński, 1994, p. 3). The autonomy and development of the human person is considered in this approach as the autonomy of a person fostering bonding with others and not as the autonomy of a person becoming independent of relationships with others.

\section{Subjectivity and autonomy in theory and in research volume contents}

The volume contains six articles written by developmental psychologists, researchers with many years of experience. Each of these texts provides new scientific knowledge about human subjectivity and autonomy in the relevant sphere of their functioning.

Adam Niemczyński, in the article titled "Autonomy of human mind and personality development", develops and further pursues the original concept of the autonomy of development of the person coined in the 1990s. In his article, the Author undertakes to identify the subject and objectives of psychological research on the individual development of a person. The concept of the autonomy of human development outlined in earlier papers (Niemczyński, 1992, 1994, 2007) has now been expanded. The author focuses on the autonomy of the development of the human mind and personality. A premise underpinning the Author's deliberations is the explication made by Macnamara (1999) concerning the constitutive property of the human mind, which consists of the subject relating to the object in an act of the mind. This relationship of "the subject relating to the object" sets out, according to Niemczyński, the autonomous area of the mind and personality. The Author refers the concept of autonomy to individual human development. He also considers that the things of the mind should not be reduced to biological things. The processes taking place in these areas are governed by different laws. Niemczyński already emphasised this in earlier studies (1992, 1994, and 2007). In this article, however, he focuses on the two-partite "subject-object" relationship because he believes that it requires special attention if a greater insight is to be gained into the mind and personality in their autonomy.

Czesław Walesa, Elżbieta Rydz, and Małgorzata Tatala in the article "Test of the Structure and Level of Religiosity" present a proprietary tool for measuring these variables. Its underlying theoretical foundation is the cognitive developmental theory of integral development by Walesa $(1997,2005$, and 2008). In his theory, the Author identified nine periods of development of human religiosity during the life course, from birth to late old age. The following factors are of particular importance in light of the topics discussed in this volume: the period of formation of autonomous religiosity (12-17 years of age), the period of religious authenticity (18-24 years of age), the period of realistic and stable religiosity (25-39 years of age), the period of fulfilled religiosity (40-60 years of age), and the religiosity of an aging person (over 60 years of age).

The presented test of religiosity is based on a holistic theory of religiosity, which assumes that its specific features are manifested at each of the stages of development and in different domains of human functioning. Religious reality is autotelic in nature, whereas the actual test serves theoretical, research and practical purposes. Religiousness concerns the spiritual sphere of the human being, a human person as an autonomous subject.

Maria Czerwińska-Jasiewicz, in the article "The creation of a concept of one's own life by adolescents as a manifestation of subjectivity and autonomy", presents an original notion concerning the formation of personal life concepts during adolescence, which is treated as a manifestation of subjectivity and autonomy. The Author bases her deliberations on two theoretical concepts: Piaget's (1970), concerning the formation of a life design during adolescence, and Niemczyński's (1980, $1988,1994)$, on the formation of an own life concept by a person during their life course. She presents an extended version of her original model of adolescents' concepts on their own lives (Czerwińska-Jasiewicz, 2005, 2007, 2011, 2015). In this model, she indicates the main elements of the own life concept of adolescents (preferred lifestyle, life goals, plans and decisions), and also discusses the main factors affecting the formation of this concept (value system, social factors, general development related factors, and individual characteristics). She then supports the thesis that the creation by adolescents of concepts of their own life during adolescence demonstrates subjectivity and autonomy. In the substantiation, she uses examples of her own research outcomes (Czerwińska-Jasiewicz, 2005, 2015) and showcases the views and results of research conducted by other authors (Nuttin, 1980; Nurmi, 1991; Trempała \& Malmberg, 1996; and Zaleski, 1991).

It is important to note that there is very limited knowledge of this subject. It is supplemented and enriched by the presented research results and the discussed original model of own life concepts of adolescents.

The article of Ludwika Wojciechowska titled "Subjectivity and generativity in midlife" concerns the relationship between subjectivity and generativity and the subjective well-being in middle-aged persons. It is important to highlight that no such considerations or empirical research have been undertaken in Polish psychology. The results of original research on the relationship between generativity and subjective well-being during middle adulthood have been set out in the article. 
This is the first attempt to study this dependency. The research was based on the theory of Erikson (1997, 2002), McAdams (2001), and Kotre and Kotre (1998). The findings of this research confirmed the positive relationship between generativity and subjective well-being and human subjectivity.

Maria Straś-Romanowska in her article "The subjectiveness of older adults in the late works of eminent creators" analyses the subjectivity of an elderly person reflected in the works of illustrious artists. The Author sets out her considerations in light of the premises of personalism (Straś-Romanowska, 1999, 2004, 2010). She points to a specific developmental trend of increasing inner subjectivity with age. It is characterised by a greater reflectivity, a focus on one's own experiences and memories, and the summing up of their experiences to date. An openness to spiritual values is evident in the works of older artists. This is one of the few studies devoted to the analysis of creativity in late adulthood as a specific manifestation of subjectivity. This is indeed an original and excellently organised study written by a master and thinker who organises current knowledge in the aforementioned fields, pointing to the most significant elements and making an apt selection of examples showcasing the presented issue.

Wanda Zagórska, in her article "Discovering subjectivity: A subjective world of meanings in the stories of the twilight of life" also analyses the signs of the human person's subjectivity in later adulthood but does so on the basis of empirical research. She examines subjectivity in the hermeneutics mainstream (Zagórska, 2011, 2012), on the border between psychology and philosophy, and empirically verifies the effectiveness of the method. The stories of elderly persons are analysed and interpreted in terms of the world of subjective meanings that they contain. This world is an empirically tangible manifestation of subjectivity. The Author points to the advantages of interpreting self-narration based on hermeneutic analysis. An undeniable value of this study is the presentation of the structure of the interview intended to provide the utmost motivation to disclose subjective meanings but also to facilitate the highest degree of interpretative compliance possible.

\section{Conclusions}

The presented volume entails attempts to proffer the issue of subjectivity and autonomy from the perspective of human development during the life course. This volume comprises original studies relating to selected developmental stages (adolescence, medium and late adulthood) and human functioning in the sphere of personality and mind, religiousness, the creation of one's own life concept, generativity, creativity and selfnarration pertaining to one's own life. Another important outcome of this collection is improving the knowledge of subjectivity and human autonomy from a developmental perspective through the original concepts, considerations and analyses set out in this scope. The innovativeness of these approaches and their original contribution to science must also be emphasised.

1) The theory of Niemczyński concerning the autonomy of human development is one of the few and most valuable contemporary theories of development during the life course. The Author originally relates the concept of autonomy to personal development. He also draws attention to the fact that acts of the mind are performed as "relations of the subject to the object". This relationship - manifest in the form of thoughts, concerns, perceptions, expectations of memories, desires, and convictions - establishes the autonomous fields of the mind and personality. According to Niemczyński, nothing but the mind works in this way in the real world. The author of this theory strongly emphasises the non-reducibility of what is of the mind to what is biological. The processes taking place in these areas are governed by different laws.

2) The theory of Walesa concerning the development of the religiousness of a human person during the life course is cognitive and developmental in nature. It is closely linked to the theoretical approaches of this nature, which explain religiousness through its structure and functions in relation to specific stages of development. He refers to the stage structure mainstream concept of the development of religiousness, comprising the theories of Fowler, Goldman, Elkind and Oser, as well as Gmunder (Walesa, 2005). The article of Walesa, Rydz and Tatala also presents the original Test of the Structure and Level of Religiosity, the theoretical basis of which is Walesa's theory. It not only brings new knowledge concerning the development of religiousness of a human person but also gives valuable information on the new method of measurement of the structure and level of religiousness during the life course.

3) The theoretical model of Czerwińska-Jasiewicz (cf. 2005, 2015) concerns the concepts of adolescents on their own lives as a phenomenon that is specific to adolescence. The Author acknowledged this specific and common action of adolescents as a manifestation of their subjectivity and autonomy. Studies on this topic are few and far between, both in current and past psychological literature. The most valuable in this respect are the studies of Piaget (1970) and Niemczyński (1980, 1988, 1994). The article presents an extended version of the mentioned model and examples of results of the Author's own research verifying the model. Notably, contemporary psychological literature lacked such a model.

4) The elaboration of Wojciechowska presents the first attempt in Poland of researching the relationship between subjectivity and well-being and generativity during middle adulthood. The research was based on the theory of Erikson (1997, 2002), McAdams (2001), and Kotre and Kotre (1998). The results confirmed the relationship between subjectivity and well-being and generativity. They provide new information about the 
positive relationship between the subjectivity of an adult and their generative attitudes and behaviours.

5) The article of Straś-Romanowska on the subjectivity of persons in late adulthood concerns the oeuvres analysed on the basis of the texts of famous writers in their senior years. The Author presents the issues undertaken with the competence of a leading representative of the personalism mainstream in Polish psychology. This is one of the very few studies on this topic kept within this mainstream.

6) The study of Zagórska brings valuable new information about the subjective nature of human life in late adulthood. This nature is manifest in the world of personal meanings of senior citizens studied by her, most fully revealed in the self-narration created in contact with another person (Zagórska, 2011, 2012). It is worth drawing attention to the valuable method of studying and analysing hermeneutic in nature results presented herein.

Apart from invaluable new knowledge on subjectivity and autonomy from a developmental perspective, the presented studies also constitute an attempt to develop and deepen the discussion and deliberations concerning the meaning of subjectivity and autonomy in the development and the functioning of the human person during their life course.

\section{References}

Bobryk, J. (1981). Spoleczne podstawy Ja podmiotowego [Social basis of the subjective self]. Warsaw: Wydawnictwa Uniwersytetu Warszawskiego.

Czerwińska-Jasiewicz, M. (2005). Rozwój psychiczny młodzieży a jej koncepcje dotyczace wlasnego życia [The psychical development of adolescents and their concepts on their own lives]. Warsaw: Wydawnictwo Instytutu Psychologii PAN.

Czerwińska-Jasiewicz, M. (2007). Adolescents concepts on their own lives. A new research model and synthesis proposal. Polish Psychological Bulletin, 38(3), 149-155.

Czerwińska-Jasiewicz, M. (2011). The significance of adolescents value system in creating concepts of their own life. Polish Psychological Bulletin, 42(4), 1-10.

Czerwińska-Jasiewicz, M. (2015). Psychologia rozwoju młodzieży w kontekście biegu ludzkiego życia [The developmental psychology of adolescents in the context of the human life course]. Warsaw: Difin.

Erikson, E.H. (1968). Youth and crisis. New York-London: W.W. Norton \& Company.

Erikson, E. (1994). Identity and the life cycle. New York-London: W.W. Norton \& Company.

Erikson, E.H. (1997). Dzieciństwo i społeczeństwo [Childhood and society]. Poznan: Dom Wydawniczy Rebis.

Erikson, E.H. (2002). Dopetniony cykl życia [Fulfilled life course]. Poznan: Rebis.

Gasiul, H. (2006). Psychologia osobowości. Nurty, teorie, koncepcje [Personality psychology. Mainstreams, theories and concepts]. Warsaw: Difin.

Inhelder, B., Piaget, J. (1970). Od logiki dziecka do logiki młodzieży [From the logic of a child to the logic of adolescents]. Warsaw: Państwowe Wydawnictwo Naukowe.

James, W. (1892). Psychology: briefer course. New York: Henry Holt and Company.

Jarymowicz, M. (2008). Psychologiczne podstawy podmiotowości [The psychological bases for subjectivity]. Warsaw: Państwowe Wydawnictwo Naukowe.
Kotre, J., Kotre, K.B. (1998). Intergenerational buffers: 'The damage stops here'. In D.P. McAdams, E. de St. Aubin (eds.), Generativity and adult development: How and why we care the next generation (pp. 367-389). Washington: American Psychologist Association.

Labouvie-Vief, G. (1982). Dynamic development and mature autonomy: A theoretical prologue. Human Development, 25, 161-191.

Labouvie-Vief, G. (1992). A neo-Piagetian perspective on adult cognitive development. In R.J. Sternberg, C.A. Berg (eds.), Intellectual development (pp. 197-228). New York: Cambridge University Press.

Majczyna, M. (2000). Podmiotowość a tożsamość [Subjectivity versus identity]. In A. Gałdowa (ed.), Tożsamość człowieka [Human identity] (pp. 35-52). Krakow: Wydawnictwo Uniwersytetu Jagiellońskiego.

McAdams, D.P. (2001). Generativity in midlife. In M.E. Lachman (ed.), Handbook of midlife development (pp. 395-443). New York: John Wiley \& Sons, Inc.

Niemczyński, A. (1980). Modele indywidualnego rozwoju człowieka [Models of individual human development]. Krakow: Wydawnictwo Uniwersytetu Jagiellońskiego.

Niemczyński, A. (1988). Procesy rozwojowe w pełnym cyklu życia indywidualnego [Developmental processes in the complete individual life course]. In M. Tyszkowa (ed.), Rozwój psychiczny człowieka $w$ ciagu życia [Human psychological development during the life course] (pp. 223-233) Warsaw: Państwowe Wydawnictwo Naukowe.

Niemczyński, A. (1992). Origins of human autonomy: A dialectics of adolescence growing into adulthood. Polish Psychological Bulletin, 23(1), 75-82.

Niemczyński, A. (1994). O autonomii rozwoju. Zarys problematyki [On the autonomy of development. An overview]. Kwartalnik Polskiej Psychologii Rozwojowej, 2(1), 3-11.

Niemczyński, A. (2007). Inner regulatory device for adult development. Polish Psychological Bulletin, 38(3), 133-139.

Nurmi, J.E. (1991). How do adolescents see their future? A review of the development of the future orientation and planning. Developmental Review, 11, 1-59.

Nuttin, J. (1980). Motivation et perspective d'avenir. Louvain: Presses Universitaires.

Obuchowski, K. (1977). Autonomia jednostki a osobowość [The autonomy of an individual versus personality]. In J. Reykowski, O.W. Owczynnikowa, K. Obuchowski (ed.), Studia z psychologii emocji, motywacji $i$ osobowości [Studies on the psychology of emotions, motivation, and personality] (pp. 77-101). Wroclaw: Zakład Narodowy im. Ossolińskich.

Obuchowski, K. (1995). Przez galaktyke potrzeb [Through the galaxy of needs]. Poznan: Zysk i S-ka.

Piaget, J., Inhelder, B. (1989). La psychologie de l'enfant. Paris: Presses Universitaires de France.

Pervin, L.A., John, O.P. (1997). Personality: Theory and research ( $7^{\text {th }}$ ed.). New York: Wiley.

Podsiad, A., Więckowski, Z. (ed.) (1983). Mały słownik terminów i pojęć filozoficznych dla studiujacych filozofię chrześcijańska [A small dictionary of philosophical terms and concepts for students of Christian philosophy]. Warsaw: Instytut Wydawniczy PAX.

Popielski, K. (1994). Noetyczny wymiar osobowości [The noetic dimension of personality]. Lublin: Redakcja Wydawnictw KUL.

Reber, A.S. (1985). Dictionary of psychology. London: Penguin Books.

Reykowski, J. (1988). Podmiotowość - szkic problematyki [Subjectivity - an outlines of the issues]. In P. Buczkowski, R. Cichocki (ed.), Podmiotowość: możliwość - rzeczywistość - konieczność [Subjectivity: possibility - reality - necessity]. Poznan: Wydawnictwo Ośrodka Analiz Społecznych.

Sotwin, W. (2006). Głos w dyskusji: Człowiek jako podmiot zachowania w ujęciu psychologicznym [A voice in the discussion: The human person as the subject of behaviour in the psychological approach]. Diametros, 7, 145-154.

Sotwin, W. (2010). Jak działa wola, czyli dynamika umystu [How the will acts, thus, the dynamics of the mind]. Warsaw: Wydawnictwo SWPS Academica.

Stachowski, R. (2002). Historyczne korzenie idei personalizmu w psychologii [Historical roots of the idea of personalism in psychology]. Studia Psychologica, 3(3), 69-82. 
Straś-Romanowska, M. (1999). Rozwój osobowy. Próba konceptualizacji problemu w nawiązaniu do psychologii life-span [Personal development. An attempt to conceptualise the issue with regard to life-span psychology]. Forum Psychologiczne, 4, 115-127.

Straś-Romanowska, M. (2004). Podmiotowość człowieka w badaniach narracyjnych [Human subjectivity in narrative studies]. In E. Dryll, A. Cierpka (ed.), Narracja. Koncepcje $i$ badania psychologiczne [Narration. Psychological concepts and studies] (pp. 23-36). Warsaw: Wydawnictwo Instytutu Psychologii PAN.

Straś-Romanowska, M. (2011). Podmiot osobowy w świecie współczesnym [The personal subject in the contemporary world]. Psychologia Rozwojowa, 2(21), 15-25. doi: 10.4467/20843879PR.16.007.5085

Trempała, J., Malmberg, L. (1996). Dorosłość w oczekiwaniach młodzieży polskiej i fińskiej [Adulthood in the expectations of Polish and Finnish adolescents]. Forum Psychologiczne, 1(1-2), 59-70.

Uchnast, Z. (1990a). Humanistyczna orientacja w psychologii osobowości [The humanistic orientation in psychology of personality]. Lublin: Roczniki Wydawnicze KUL.

Uchnast, Z. (1990b). Problem podmiotowości w ujęciu psychologicznym [The issue of subjectivity in a psychological approach]. Przeglad Psychologiczny, 33(1), 41-57.

Walesa, Cz. (1997). Psychologiczna analiza zmian w rozwoju religijności człowieka [A psychological analysis of the changes in the religiosity of a human person]. Roczniki Filozoficzne-Psychologia, 45(4), $109-132$.

Walesa, Cz. (2005). Rozwój religijności człowieka, t. 1: Dziecko [The development of human religiosity, v. 1: The Child]. Lublin: Wydawnictwa Katolickiego Uniwersytetu Lubelskiego.
Walesa, Cz. (2008). Rozwój religijności młodzieży [The development of the religiousness of adolescents]. In Encyklopedia katolicka, t. 12 [Catholic Encyclopaedia, v. 12]. Lublin: Towarzystwo Naukowe KUL.

Zagórska, W. (2011). Subject-subject relation as a significant aspect of personal development in adulthood. Polish Psychological Bulletin 42(4), 181-187. DOI: 10.2478/v10059-011-0024-8

Zagórska, W. (2012). Relacja podmiotowa na drogach rozwoju osobowego [The subjective relationship on the paths of personal development]. Horyzonty Psychologii, v. II, 89-103.

Zagórska, W. (2015a). Kryzys relacji podmiotowej jako kryzys dojrzewania $w$ czlowieczeństwie [The crisis of the subjective relationship as the crisis of maturation in humanity]. Lecture delivered at the $47^{\text {th }}$ Symposium of the Section of Psychology at the Polish Bishops Conference Committee for the Doctrine of the Faith: Współczesne konflikty i kryzysy egzystencjalne i religijne [Contemporary existential and religious conflicts and crises]. Gniezno, 20-22 September.

Zagórska, W. (2015b). Relacja podmiotowa (Ja-Ty) w pismach ks. prof. Tadeusza Dajczera [The subjective relationship (I-Thou) in the writings of Rev. Prof. Tadeusz Dajczer]. Scientific symposium: Madry przewodnik w drodze do prawdy ks. prof. Tadeusz Dajczer (1931-2009) [Rev. Prof. Tadeusz Dajczer (1931-2009). A wise guide on the path to the truth]. Warsaw, 26 November.

Zaleski, Z. (1991). Psychologia zachowan celowych [The psychology of purposeful behaviour]. Warsaw: Państwowe Wydawnictwo Naukowe. 